\title{
KURIOS
}

(Jurnal Teologi dan Pendidikan Agama Kristen)

Vol. 2, No. 1, Oktober 2014 (20-25)

ISSN 2406-8306 (print)

http://www.sttpb.ac.id/e-journal/index.php/kurios

\section{A Critical Analysis of God's Righteousness in Romans 1: 16-17}

\author{
Halim Wiryadinata \\ Sekolah Tinggi Teologi Pelita Bangsa Jakarta \\ ketua@sttpb.ac.id
}

\begin{abstract}
This article brings the new approach for the book of Romans especially the word of God's righteousness is the central pint point for the theology of the Apostle Paul. God's righteousness is another attempt for solving the arguments of interpreting the book of Romans.
\end{abstract}

\section{Introduction}

It is a great opportunity to share a wonderful idea for the big theme 'Being the Truthful and Faithful Friend' in the light of the term "the Righteousness of God" in Romans 7: 16-17. We should be grateful for the invitation to share the thought being able to contribute the article for the Light of the Nation School of Theology (STT Pelita Bangsa). The righteousness of God plays important role in the book of Romans for understanding God's plan of salvation for Jews and Gentiles. ${ }^{1}$ In other words, God's righteousness is 'the covenant faithfulness of God', for at the end of the day God Himself will vindicate His people and bestow them the status of the righteous. ${ }^{2}$ Therefore, this article will be divided into three main streams, where first of all we see the background of the righteousness of God and secondly, we challenge it.

\section{The Background of the Righteousness of God}

We shall see the background of the righteousness of God from the beginning by its definition. The terminology of the righteousness of God comes from the interpretation, which has difficulty of the meaning of the word 'righteousness of God' itself. Ralph Martin says that

1 See Wright, N.T., What Saint Paul Really Said (Was Paul of Tarsus the Real Founder of Christianity?), (Oxford: A Lion Book, 1997), p. 107.

${ }^{2}$ See ibid., p. 89. 
the words neither exist by themselves without a context nor are the text written as free. ${ }^{3} \mathrm{He}$ insists that floating packages of meaning without a historical basis or a place in their cultural milieu. ${ }^{4}$ However, the concept of the righteousness of God in the Hebrew Bible emphasises the relational aspect of God and humanity in the context of a covenant. ${ }^{5}$ The common Hebrew word for righteousness is sedeq or its feminine form sedeqa which occurs in the Old Testament 117 and 115 times respectively. Usually the word suggests Yahweh's saving acts as evidence of God's faithfulness to the covenant. ${ }^{6}$ Therefore, the righteousness of God denotes God's redemptive activity and not God's gift of righteousness to us which leads to salvation.

This little background will lead us to see what are the current views of thought on the subject of the righteousness of God. As a result, we have to move on to look at the righteousness of God and its debates.

\section{Pembahasan}

\section{The Righteousness of God and Its Debates}

The arguments of the righteousness of God starts when Kasemann sees Romans 3: 5; 25-26 as referring to God's character to emphasise that Paul's view of the righteousness of God accents its gift-character against the backdrop of Jewish apocalyptism. ${ }^{7}$ In other words, Kasemann says the gift itself has the character of power and salvation creating power. ${ }^{8}$ The gift is never a personal possession separated from the giver. In this way, Kasemann captures the eschatological nature of the relationship of God in a forward orientation toward the consummation of God's saving acts in Jesus Christ. If it is so, then Kasemann will conclude that God's faithfulness is faithfulness to creation, not simply to the individual. He insists strongly that salvation is experienced in the sphere of Christ's lordship, which is entered in response to God's righteousness. ${ }^{9}$ As a result, God's sovereignty over the universe is established eschatologically in Jesus Christ.

From what have been said above, Stuhlmacher, who is the student of Kasemann, stresses the aspect of the righteousness of God in that the creator makes right the world on account of his creation - faithfulness, even by raising the dead. ${ }^{10}$ The righteousness of God is

\footnotetext{
${ }^{3}$ Martin Ralph, Dictionary of Paul and His Letters, (Leicester: IVP, 1993), p. 828.

${ }^{4}$ Ibid.

${ }^{5}$ Ibid.

${ }^{6}$ Ibid.

${ }^{7}$ See Kasemann, Ernst, Commentary on Romans, (Michigan: William B Eerdmans, 1980), p. 27.

${ }^{8}$ Ibid.

${ }^{9}$ Ibid.

${ }^{10}$ See Martin, Ralph, Loc. Cit., p. 835.
} 
God's creating power fostering faith and recreating the world. Stuhlmacher sees the righteousness of God as the centre of Paul's theology whereby Paul shows a complete correlation between judicial and ontological ideas of righteousness. Therefore, justification, according to Stuhlmacher, refers to a divine creativity, the actualisation of the righteousness of God as 'Word event' which creates a new being at baptism. ${ }^{11}$

However, Wright builds up his basic premise on the one hand, on the debate between Kasemann and Stendahl ${ }^{12}$, and on the other hand, the "covenant nomism'13 of E. P. sanders. ${ }^{14}$ Kasemann says that God's righteousness is perhaps the most important theme in Paul's writings, because this is taken over by Paul from apocalyptic Judaism. ${ }^{15}$ Kasemann goes on to argue that the righteousness of God is subjective genitive - speaking of a divine activity. Thus, the righteousness of God, according to Kasemann, is "salvation-creating activity and has been defined as God's victorious, creation-covenant-faithful power-action. "16 In contrast, Luther's position is that the righteousness of God refers to the righteousness, which counts in His sight and which humanity possesses as a gift from Him. ${ }^{17}$ Stendahl criticises Kasemann when he says that Kasemann fails to interpret God's righteousness in salvation history framework. ${ }^{18}$ Stendahl insists that "the salvation history is the basic of Paul's theology and justification by faith is part of Paul's apologetics for the Gentile mission and the place of Gentiles in the church."19 Wright endorses Stendahl when he says "Stendahl is absolutely right to draw attention to Paul's robust conscience and to the fact that justification and salvation history have a habit of keeping close company in Paul." 20

\footnotetext{
${ }^{11}$ Ibid.

${ }^{12}$ See Wright, Nicholas Tom, The Paul of History and the Apostle of Faith, Tyndale Bulletin, (Vol. 29, 1978), p. 71.

${ }^{13}$ Covenant nomism means, according to Sanders, Torah as given to Israel as part of God's covenant with Israel, obedience to the law of Moses as part of God's choice of Israel to be his people, nomism as the way of living within the covenant, maintaining and manifesting status as the people of Yahweh. (See Dunn, James, The Parting of the Ways (between Christianity and Judaism and their Significance for the Character of Christ), (London: SCM Press, 1991), p. 24.

${ }^{14}$ See Eveson, Philip, The Great Exchange: Justification by Faith alone in the light of recent thought, (Bromley: Day One Publication, 1996), pp. 126-127.

${ }^{15}$ Ibid., p. 71, and see Dan. 6: 10, 1 QS 11: 12; Det. 33: 21.

${ }^{16}$ Kasemann, which is cited on O'Brien, P. T., 'Justification in Paul and Some Crucial Issues of the Last Two Decades', ed. D. A. Carson, Right with God (Justification in the Bible and the World), (Michigan: Baker House, 1992), p. 71. Romans.

${ }^{17}$ Ibid. Luther's position is that Justification by faith is the central theme of Paul in the letter to the

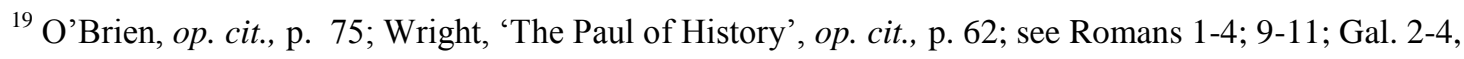

${ }^{19}$ O’Brien, op. cit., p. 75; Wright, 'The Paul of History', op. cit., p. 62; see Romans 1-4; 9-11; Gal. 2-4, 63.

${ }^{18}$ See Wright, 'The Paul of History and the Apostle of Faith' (hereafter The Paul of History), op. cit., p. Philip. 3.

${ }^{20}$ Wright, 'The Paul of History', op.cit. p. 86.
} 
Kasemann, however, argues that Stendahl's argument has no place for a theology of the cross or for any strong Pauline emphasis on the discontinuity between Christianity and Judaism. $^{21}$ Stendahl argues back that Jews have their own way of salvation apart from Christ. $^{22}$ Thus, it leads on, on the other hand, for Wright to accept the main conclusion of Sanders when he says “on Paul's day God's righteousness does not have any idea as a legalistic religion to earn righteousness and merit God's favour by good works. "23 Sander's basic premise is that, according to Rabbinic Judaism, forgiveness depends upon God's goodness and generosity. ${ }^{24}$ The word 'salvation, to the first century Jews, is the gift of God through the membership within the covenant. ${ }^{25}$ So, it does not surprise us that Sanders concludes "...salvation is by grace, but judgement is according to works; works are the condition of remaining 'in', but they do not earn salvation. ${ }^{26}$ It is not because, according to Sanders, Jews seek to save themselves and become self righteous, but "it depends upon their status as God's covenant people who possess the law and as result miss out on the better righteousness based solely on believing participation on Christ. "27

In other words the obedience to the law does not mean entering the covenant or establishing the covenant, but a means of maintaining (or staying in) the covenant relationship. ${ }^{28}$ This, therefore, leads Wright to conclude that God's righteousness is the divine covenant faithfulness of God. ${ }^{29}$ Therefore, Kasemann also sees further progress is made with the insight that the biblical usage of righteousness, which is essentially forensic, denotes a relation in which one is set, namely recognition in which one, for example, is acknowledge to be innocent. ${ }^{30}$ In Jewish apocalyptic this understanding is applied to the verdict of justification at the last judgement. Justification, at first the first presupposition and condition of salvation, and thus becomes itself the benefit of salvation. This is at least true for Paul, especially in the key verse Phil. 3: 9 in which God's righteousness, reminiscent of Isaiah 54: 17 seem to be directly defined by the righteousness of God.

\footnotetext{
${ }^{21}$ Ibid., p. 64.

22 Ibid.

${ }^{23}$ Wright, N. T., New Testament and The People of God, (London: SPCK, 1992), p. 334.

${ }^{24}$ See O'Brien, op. cit., p. 86.

${ }^{25}$ Wright, N. T., NTPG, op. cit., p. 86.

${ }^{26}$ Sanders E. P., Paul and Palestinian Judaism, (London: SCM Press, 1977), p. 543.

${ }^{27}$ Sanders, which is cited on O'Brien, op. cit., p. 86.

${ }^{28}$ See Sanders, which is cited on Wright N. T., What Saint Paul really Said, op. cit., p. 18-19.

${ }^{29}$ Wright, N. T., 'Romans and the Theology of Paul, ed. David M. Hay and Elizabeth Johnson, Pauline theology vol. III Romans, (Minneapolis: Fortress Press, 1995), p. 33.

${ }^{30}$ See Kasemann, p. 24.
} 


\section{The Righteousness of God in the Letter to Romans}

God's righteousness in the book of Romans has revealed the covenant faithfulness of God in the Gospels of Jesus, the messiah. ${ }^{31}$ Wright assumes that the sequence of Romans 111 is based on "a Jewish covenantal scheme of thought, granted that the latter has been rethought in the light of the belief that its future hope has already in principle come true in the Messiah, Jesus, and I snow being implemented by the Spirit." 32 Having said that, one central point in Romans, according to Wright, is that Paul seems to regard that the historical people of Abraham should be the answer of Adam's sin and the light to the world. However, Israel as a nation fails to on this task, because she is not guilty of legalism, but what Wright calls 'national righteousness'. ${ }^{33}$ Therefore, he insists in Romans 2: 19 -29 that Paul is not attacking Judaism, because it is legalistic, but Paul criticises Jews, because they are proud of their national superiority. ${ }^{34}$

There are four things that we should bear in our mind for Romans 2: 17 -29: first of all, Jews boast in God claiming that God is the God of the Jews, not of the Gentiles. Secondly, Jews break the law and fall into sin. Thirdly, Jews abuse the law as 'national righteousness' because of the fact that Jews have privileges in the eyes of God. Finally, Paul criticises Jews, because they trust the law and circumcision as the badge of national privilege. ${ }^{35}$ Therefore, Romans 3: $21-31$ is just such a solution for the Covenant of God to deal with evil in the world and with its consequence i.e. wrath. ${ }^{36}$ As a result, God's righteousness is then invoked as the reason why He can be expected to deliver His people and He is committed by covenant to so do.

From what have been said above, it leads us to see the reality of the righteousness of God consisting of nothing except the new relationship between God and humanity created by God, whom from the divine side is lordship and from human side is obedience. Thus, for Paul, the present and the future character of God's eschatological redemption are essentially identical, because both have their basis in the Christ event. Righteousness is by faith, not as a possession, but a relationship in which one acknowledges God's claim upon one's life.

\footnotetext{
${ }^{31}$ Wright, N. T., Romans and The Theology of Paul, op. cit., p. 34.

${ }^{32}$ Ibid., p. 36; see Wright N. T., The Climax of the Covenant, (Edinburg: T\&T Clark, 1991), p. 225.

${ }^{33}$ See Wright, N. T., The Pal of History, op. cit., p. 65; National righteousness means the belief of that fleshly Jewish descends guarantees membership of God's covenant people.

${ }^{34}$ See Eveson, op. cit., p. 112.

${ }^{35}$ See Wright, 'The Paul of History', p. 82.

${ }^{36}$ Ibid., p. 37; see 3: 2, looking back to 2: $17-29$ and onto 5: 20 and 7: 7-25, where this points out the fact of sin that the covenant God will deal with it.
} 


\section{Conclusion}

For the righteousness of God, it is an absolutely magnificent construction as genitive grammar in the Greek New Testament. It is a prominent area to consider seeing how the redemption of the Messiah has already given the righteousness of God (or the covenant faithfulness of God to His people) to be revealed. The righteousness of God cannot be separated with the work of the Messiah upon the Cross, because it brings us in order to see how truthful and faithful our God is to His covenant to redeem us to be His people.

\section{References}

Dunn, James, The Parting of the Ways (between Christianity and Judaism and their Significance for the Character of Christ), (London: SCM Press, 1991).

Eveson, Philip, The Great Exchange: Justification by Faith alone in the light of recent thought, (Bromley: Day One Publication, 1996).

Hay and Elizabeth Johnson, Pauline theology vol. III Romans, (Minneapolis: Fortress Press, 1995)

Kasemann, which is cited on O'Brien, P. T. 'Justification in Paul and Some Crucial Issues of the Last Two Decades', ed. D. A. Carson, Right with God (Justification in the Bible and the World), (Michigan: Baker House, 1992).

Kasemann, Ernst, Commentary on Romans, (Michigan: William B Eerdmans, 1980).

Luther's position is that Justification by faith is the central theme of Paul in the letter to the Romans. See Wright, 'The Paul of History and the Apostle of Faith' (hereafter The Paul of History).

Martin Ralph, Dictionary of Paul and His Letters, (Leicester: IVP)

Sanders E. P.Paul and Palestinian Judaism, (London: SCM Press, 1977)

Wright, N. T. New Testament and The People of God, (London: SPCK, 1992)

'Romans and the Theology of Paul, ed. David M. 1978).

The Paul of History and the Apostle of Faith, Tyndale Bulletin, (Vol. 29, . What Saint Paul Really Said (Was Paul of Tarsus the Real Founder of Christianity?), (Oxford: A Lion Book, 1997) 